\title{
Pedro Nolasco Baptista: traços biográficos e atividades musicais em Pernambuco \\ (1832-1865)
}

Pedro Nolasco Baptista: biographical data and musical activities in Pernambuco (1832-1865)

Humberto Amorim Universidade Federal do Rio de Janeiro (UFRJ) humbertoamorim@ufri.br 


\section{Resumo}

O artigo objetiva resgatar a trajetória $e$ as atividades musicais de um personagem que atuou em Pernambuco entre as décadas de 1830 e 1860: Pedro Nolasco Baptista (? 1865). Músico de múltipla atuação, Nolasco teve passagens pela corte do Rio de Janeiro e a província do Ceará, mas foi em sua cidade natal, Recife, que alcançou um prestígio e reconhecimento singulares, trabalhando como intérprete (instrumentos de sopro e violão), compositor, professor e maestro, inclusive de orquestras e bandas militares. O método consistiu em uma pesquisa documental (levantamento, catalogação e análise crítica) que suscitou mais de 60 inéditas entradas em periódicos brasileiros oitocentistas. Os resultados apontam para a significativa inserção do artista no cenário musical pernambucano de seu tempo.

Palavras-chave: Pedro Nolasco Baptista. Oficleide no século XIX. Músicos pernambucanos oitocentistas. Música em periódicos pernambucanos.

\section{Abstract}

The article presents the trajectory and musical activities of a musician who worked in Pernambuco between the 1830s and 1860s: Pedro Nolasco Baptista (? - 1865). A multi-talented character, Nolasco worked in the court of Rio de Janeiro and also in the province of Ceará, but it was in his hometown, Recife, that he achieved prestige and recognition, working as a performer, composer, conductor and teacher. The method consisted in the survey, cataloging and critical analysis of more than 60 unpublished sources collected in eighteenth-century Brazilian periodicals. The results indicate the significant insertion of this artist in the musical scene of his time.

Keywords: Pedro Nolasco Baptista. Oficleide in the nineteenth century. Pernambuco musicians of the nineteenth century. Musical sources in newspapers from Pernambuco. 
Personagem praticamente desconhecido pela musicologia brasileira, Pedro Nolasco Baptista (? - 1865) foi um músico - compositor, maestro e multi-instrumentista - que teve uma decisiva participação nas práticas musicais realizadas no Brasil, sobretudo em Pernambuco, durante as décadas de 1830 e 1860. Através do inédito levantamento de mais de 60 entradas sobre suas atividades artísticas em periódicos do século XIX, este artigo pretende resgatar os seus principais traços biográficos e delinear parte, pelo menos, de sua inserção no bojo sociocultural brasileiro do período, revelando suas múltiplas contribuições e realizações no campo da música.

Na bibliografia disponível, as únicas referências mais concretas sobre este personagem encontram-se no livro Música e Ópera no Santa Isabel: subsídio para a história e o ensino da música no Recife, de José Amaro Santos da Silva. Nele, Nolasco é apresentado como "o músico que definiu, no século XIX, a posição de Pernambuco no cenário nacional" (SILVA, 2006: 211).

Apesar disso, na mesma página, o autor constata como os estudiosos dedicados à historiografia musical pernambucana "parecem desconhecer completamente a existência do Maestro, [...] ignorando-o completamente". À exceção das menções realizadas pelo falecido musicólogo padre Jaime Diniz (1924-1989), que o incluiu em uma relação de mestres de música militar e o classificou como "admirado compositor" em um de seus tomos sobre músicos pernambucanos do passado, pairava um enorme silêncio sobre a trajetória e as eventuais contribuições de Nolasco para a música brasileira do século XIX.

O próprio Silva tentou contornar parte de tal lacuna incluindo três páginas sobre o músico em sua já referida publicação (2006). Contudo, apesar de apresentar preciosos apontamentos e algumas inéditas fontes (mencionadas ao longo deste texto), seus esforços esbarraram nas profundas dificuldades de se realizar pesquisas musicológicas em um período no qual a maioria dos acervos públicos e/ou privados, no Brasil, ainda não haviam sido disponibilizados em versões digitais, um processo intensificado apenas durante a última década.

Além de Diniz (1979) e Silva (2006), Taborda (2004: 56) também menciona brevemente o músico ao incluí-lo dentre os professores de violão que constaram na edição de 1847 do famoso Almanak Laemmert. Estas poucas referências são o substrato do que foi publicado sobre o músico na literatura dedicada ao tema, o que nos impele a realizar, inicialmente, um esboço biográfico que permita inferir de que modo a trajetória de Nolasco se relaciona com as demandas de seu tempo e o exercício de suas atividades musicais.

\section{Pedro Nolasco Baptista: trajetória e relação com a música}

Das décadas iniciais de sua trajetória, quase nada se sabe. Os jornais publicados no Brasil ao longo da primeira metade do século XIX raramente nos revelam traços de sua vida familiar, afetiva ou social. Mesmo as informações sobre sua carreira profissional só passam a ter alguma recorrência na imprensa em meados da década de 1830. Desse modo, seu ano de nascimento e origem são desconhecidos, embora haja, em um dos 
obituários veiculados após a sua morte, a indicação de que Pernambuco seria a sua terra natal:

Os amigos e affeiçoados do grande executor pernambucano Pedro Nolasco Baptista, falecido a 24 de outubro p. passado, são convidados a ouvirem uma missa que, pelo eterno repouso de sua alma, manda celebrar um amigo do falecido, na sexta feira 24 do corrente, trigésimo dia do seu passamento $(O$ PUBLICADOR, 1865, grifo nosso).

De fato, embora Nolasco tenha passado temporadas no Rio de Janeiro e no Ceará, foi em Pernambuco que o músico permaneceu a maioria absoluta de sua vida, assumindo importantes postos profissionais como músico do exército e atuando como intérprete, maestro e/ou compositor em diversas apresentações nos teatros pernambucanos.

Em seus obituários, chama atenção a completa ausência de quaisquer de seus familiares, já que era algo comum, neste período, que os avisos de falecimento e os convites para os ritos fúnebres fossem acompanhados da assinatura de cônjuges, filhos, irmãos, etc. No caso de Nolasco, porém, a nota é rubricada por um amigo do falecido, o responsável por encomendar a missa pelo "eterno repouso de sua alma".

As poucas fontes disponiveis sobre este personagem e o fato de sua atuação artística ter se concentrado a maior parte do tempo fora do eixo RJ-SP (lugares já mais debulhados nos estudos sobre o tema) somam-se à total inexistência de notícias sobre sua família (incluindo possíveis herdeiros) como os fatores que mais concorreram para que seu nome acabasse esquecido já nos anos imediatamente posteriores à sua morte.

Pode ser que esta condição "solitária" de Nolasco tenha alguma relação com uma vida pregressa de escravo que supostamente o teria apartado dos seus muito cedo. $\mathrm{Na}$ primeira metade do século XIX, ao menos três homens com nomes iniciais homônimos ("Pedro Nolasco") circularam por Pernambuco, o que nos impede de afirmar categoricamente que, quando não acompanhada do último sobrenome ("Baptista"), uma ou outra incidência diga, de fato, respeito a ele. Entretanto, se a nota abaixo for uma referência ao músico, a escravatura nas décadas iniciais de vida explicaria a falta de notícias sobre Nolasco neste período, bem como a ausência de seus familiares nos relatos que recolhemos sobre sua trajetória entre as décadas de 1830 e 1860.

Pedro Nolasco, homem pardo, declara, que elle tendo sido escravo de João Joze da Cunha, este o libertara na ocasião, em que o anunciante expondo a vida o livrara da morte publicamente; e gozando assim de sua liberdade por alguns annos, sem contradição de alguém, succede agora, que Manoel de Araujo Cavalcante de Albuquerque Lins, morador do Engenho Paulista, o quer escravizar, figurando havêlo comprado; e como por isso trata o anunciante de provar a sua liberdade por acção competente, e para o fazer tem prestado em Juizo fiança idônea, e alcançado mandado de manutenção; avisa ao respeitavel Publico para que ninguém faça contracto algum com o dito Lins, relativamente a pessoa do anunciante, por isso mesmo que elle he liberto, e havido por tal como o hade provar (DIARIO DE PERNAMBUCO, 1831).

De qualquer modo, ainda que a passagem não se aplique ao músico, pode-se sustentar que a década de 1830 foi marcada por outro grave problema judicial para Pedro Nolasco 
Baptista. Em dezembro de 1836, uma nota assinada pelo prefeito e a promotoria da comarca de Recife nos deixa saber que Nolasco fora acusado do assassinato de um homem chamado João Gualberto, crime para o qual se buscavam testemunhas e informações complementares (DIÁRIO DE PERNAMBUCO, 1836a).

Quase seis meses depois, uma nota publicada pelo Tribunal da Comarca do Recife informa que a denúncia de assassinato fora acatada na sessão ocorrida em 29 de maio de 1837: "Jury d'Accusação. Denuncia de Maria da Conceiçaõ, Viuva de Joaõ Gualberto Ramos, pela morte d'este, denunciado Pedro Nolasco Baptista. O Jury por mais de dous terços achou materia para acusação" (DIÁRIO DE PERNAMBUCO, 1837).

Infelizmente, não encontramos registros de como o processo finalizou. O músico, contudo, voltou a frequentar as páginas policiais dois anos depois, desta vez na condição de acusador: "Foram presos hontem a minha ordem [...] José Lourenço Henrique d'Alvarenga, pardo, por outro soldado do mesmo Corpo por queixa de Pedro Nolasco Baptista de que elle lhe havia atirado uma estocada [...]" (DIÁRIO DE PERNAMBUCO, 1839).

À sombra dos graves problemas judiciais que enfrentou, engana-se, porém, quem imagina que a sua personalidade não contemplava gestos nobres. Em outubro de 1844, Nolasco perdoaria integralmente uma dívida financeira herdada pela viúva de Basílio Rodrigues Seixas, um colega músico falecido repentinamente. Publicamente, a beneficiada dedicou, a ele e a outros dos generosos amigos do marido morto, as seguintes palavras:

“[...] e muito particularmente protesta seu eterno reconhecimento e gratidão para com aquelles Srs. que, sendo tambem companheiros de musica de seu finado marido, tendo em contemplação as desgraçadas circumstancias da annunciante no seu estado de viuvez, com 9 filhos, todos menores, para sustentar, e inteiramente destituída de meios, houverão por bem de lhe perdoar as quantias adiante declaradas: [...] Pedro Nolasco Baptista - 12. 160 [réis]" (DIÁRIO DE PERNAMBUCO, 1844).

A consideração pelos colegas de profissão não se limitava aos seus contemporâneos, alcançando também as gerações passadas de mestres que foram importantes para a disseminação do ensino e da prática musical no Brasil. Ilustra o fato a missa encomendada por Nolasco, em junho de 1853, em homenagem a João dos Reis Pereira, considerado por ele como "o decano dos professores de música do Rio de Janeiro".

No Diário de Pernambuco de 2 de maio lê-se o seguinte: 'Pedro Nolasco Baptista convida a todos os seus collegas, professores de musica desta cidade, para assistirem á celebração de uma missa pela alma do nosso collega o finado João dos Reis Pereira, musico da camara de S. M. o Sr. D. João VI e do SS. MM. II. Os Srs. D. Pedro I e D. Pedro II, e decano dos professores de musica do Rio de Janeiro: bom filho, bom irmão e bom amigo. A missa terá logar na igreja do Corpo Santo, pelas 9 horas da manhã do dia 2 de maio próximo futuro, trigésimo do falecimento do commemorado' (CORREIO MERCANTIL, 1853)

Em via oposta, o respeito e consideração que alcançou de seus pares são flagrantes, sobretudo na relação estabelecida por Nolasco com os músicos dos corpos militares 
que dirigiu (conforme veremos adiante, em um dos casos, seus comandados chegaram a publicar uma nota de pesar coletiva pela sua demissão como regente de um batalhão). A carreira musical militar, aliás, foi um traço que o acompanhou, de forma quase ininterrupta, de meados da década de 1830 até o fim de sua vida. Já em abril de 1836, ele receberia do Quartel Mestre uma significativa quantia por seus trabalhos como contramestre de música em Jacuípe.

"[...] e lembro a V. S., que estando nós em Jacuípe o Contramestre della Pedro Nolasco Baptista recebeo do Quartel Mestre, por ordem do Capitaõ Manoel Florencio Alves de Moraes, que ficou Commandando o Contingente do Corpo nesta Praça a quantia de $127 \$ 470$ reis como consta de seu recibo dos descontos que se ficou fazendo aos desertados de Pannelas" (DIÁRIO DE PERNAMBUCO, 1836b).

Exatamente dez anos depois, em abril de 1846, a imprensa da região nos revela que Nolasco continuava atuante, em terras pernambucanas, como mestre de música de batalhão: "Dito - Ao mesmo, exigindo informações sobre o engajamento do mestre de musica do batalhão do seu comando, Pedro Nolasco Baptista, a vista do officio do commissario pagador, que lhe transmitia em proprio original" (DIÁRIO DE PERNAMBUCO, 1846a).

Não se sabe ao certo por quais razões o músico foi publicamente interpelado sobre o engajamento no comando musical do batalhão, mas o episódio desembocou em seu desligamento do ofício ainda naquele mês, conforme se depreende do anúncio publicado por Nolasco, no Diário de Pernambuco, oferecendo serviços como professor de canto, violão e instrumentos de sopro.

- PEDRO NOLASCO BAPTISTA faz sciente ao publico, que, não se achando mais empregado em musicas militares, recebe discípulos para qualquer instrumento de sôpro, assim como para violão e cantoria: adverte, que tanto ensina em sua casa, como na do seus discípulos, e que mora na rua das Cruzes, n. 3 (DIÁRIO DE PERNAMBUCO, 1846b, grifo nosso).

Importante registrar não somente a inclusão do violão entre os instrumentos ensinados, mas também o fato de Nolasco lecionar tanto em sua casa (Rua das Cruzes n. 3) quanto nas dos discípulos, uma prática que, no Brasil, paulatinamente se difundiu no ensino particular de música a partir da chegada da família real portuguesa e a subsequente criação da Imprensa Régia, ambos fatos ocorridos em 1808.

Apesar de seus reclames e do tempo disponível para ensinar, o ambiente musical pernambucano parece não ter dado o retorno que Nolasco esperava para as suas aulas. Em 03 de junho de 1846, pouco mais de um mês depois da publicação de seu anúncio como professor, a seção de Avisos Diversos do Diário de Pernambuco (1846b) informa: "Pedro Nolasco Baptista retira-se para os portos do Sul [...]". Cerca de três semanas depois, o mesmo jornal acrescenta que o músico foi um dos passageiros do vapor brasileiro Imperador, que tinha como destino o Rio de Janeiro, passando por escalas em Maceió e Bahia (DIÁRIO DE PERNAMBUCO, 1846c).

A data de chegada e o tempo de permanência no Rio de Janeiro são confusos. É possível que Nolasco tenha se demorado em algum destes lugares, uma vez que os 
movimentos dos portos cariocas só registram a sua entrada no Rio de Janeiro em 23 de novembro de 1846, cinco meses depois da partida de Recife, a bordo de uma outra embarcação partida da Bahia, a sumaca ${ }^{1}$ Tentativa (JORNAL DO COMMERCIO, 1846).

Contudo, anúncios oferecendo seus serviços como professor de música (incluindo aulas de violão e guitarra francesa) são anotados na imprensa carioca já nos dias 03, 18 e 23 de novembro, inclusive com indicação do endereço no número 156 da rua Senhor dos Passos, centro comercial do Rio de Janeiro. Ou seja, o primeiro destes reclames (03/11/1846) ocorre vinte dias antes de seu provável desembarque na cidade.

-- PEDRO Nolasco Baptista, professor de musica, offerece-se para dar lições de musica, violão, guitarra franceza e instrumentos de sopro: as pessoas que quiserem utilizar-se do seu préstimo dirijão-se á rua do Senhor dos Passos n. 156, ou annunciem sua morada (JORNAL DO COMMERCIO, 1846b). - PEDRO Nolasco Baptista, professor de musica, offerece-se a dar por casas particulares lições da sua arte, e bem assim de ophicleyde, flauta e violão, e alguns instrumentos de sopro; as pessoas que se quiserem utilizar do seu préstimo podem procura-lo na rua do Senhor dos Passos n. 156, de manhãa até às 9 horas, e de tarde das 3 horas até á noite (JORNAL DO COMMERCIO, 1846c). ${ }^{2}$

É provável que Nolasco tenha chegado antes ao Rio de Janeiro e feito uma outra viagem curta à Bahia posteriormente, o que justificaria, inclusive, a mudança nominal da embarcação que saiu do Recife (Imperador) para aquela que chegou no Rio (Tentativa). É a possibilidade mais plausível, embora faltem outros registros de sua movimentação nos portos para confirmar a hipótese. O que se pode dizer ao certo é que novembro de 1846 - seja em seu início ou final - marca o mês dos primeiros registros do músico pernambucano na capital do império brasileiro.

Se o momento preciso da chegada é dúbio, o período de sua permanência em terras cariocas não é menos controverso. O famoso Almanak Laemmert, publicação inaugurada em 1844 e que concentrava os anúncios administrativos, mercantis, industriais e comerciais do Rio de Janeiro em uma edição anual, incorpora o nome de Nolasco em sua seção de Professores de Música por sete anos seguidos, de 1847 até 1853, sempre indicando o seu logradouro como sito à rua do Senhor dos Passos, n. 156.

\section{Pedro Nolasco Baptista, - ophicleide, flauta e violão, - rua do Sr. dos Passos, 156.}

Fig. 1. Anúncio de Nolasco no Almanak Laemmert na edição 04, de 1847: "Pedro Nolasco Baptista, - ophicleide, flauta e violão, - rua do Sr. dos Passos, 156". A nota seria repetida nos anos de 1848, 1849, 1850, 1851, 1852 e 1853. Fonte: (ALMANAK LAEMMERT,

"Navio pequeno, à vela, geralmente com dois mastros, comum na América do Sul até o início do Século XX; usado, principalmente, em navegação de cabotagem". Fonte: https://www.dicionarioinformal.com.br/sumaca/

Acesso em 11 jun. 2018, às 00:40.

20 anúncio foi repetido no mesmo jornal em 23 de novembro de 1846 (JORNAL DO COMMERCIO, 1846d). 
Entretanto, desde maio de 1850, pelo menos, os jornais pernambucanos anotam o retorno de Nolasco à sua terra de origem, quando o músico retoma a carreira militar e é provisoriamente nomeado pelo presidente da província de Pernambuco como "professor de música instrumental do arsenal de guerra", trabalho pelo qual foi remunerado com uma "gratificação anual de 40.000 rs" (DIÁRIO DE PERNAMBUCO, 1850). Ademais, seu nome é mencionado na imprensa local em pelo menos cinco apresentações ocorridas, entre os anos de 1851 e 1853, nos palcos do Theatro de Apolo e no Theatro de Santa Isabel, conforme constataremos no tópico referente aos seus concertos.

Outro fator a corroborar sua presença em Pernambuco nos anos iniciais da década de 1850 é a direção do corpo de música do 4ํㅡ batalhão d'artilharia a pé, função da qual foi despedido no início de 1852. Vale pontuar que sua exoneração não se deu em função de uma eventual falta de capacidade ou negligência, mas sim pelo alto valor salarial que lhe era pago. A esta altura, o maestro era considerado a maior referência da região no comando musical de batalhões militares. Não à toa, o prestígio e reconhecimento galgados entre os oficiais músicos motivaram uma laudatória nota de pesar coletiva, publicada por seus comandados logo após o desligamento.

\begin{abstract}
Communicado. - Havendo sido o Sr. Pedro Nolasco Baptista exonerado da direcção da musica do $4^{\circ}$ batalhão d'artilharia a pé, não porque tivesse dado a mais simples causa, mas sim por não ser possível ao batalhão gratifica-lo em relação ao seu bem conhecido mérito, nós officiaes do supra mencionado batalhão, deixaríamos de cumprir com o dever da equidade, justiça e gratidão se publicamente não patenteássemos o nosso grande pezar por uma perda, que julgamos irreparável, pois que não sabemos se haverá aqui alguém bastante hábil para substitui-lo capazmente, ou pelo menos imita-lo.

Vimos a musica do nosso batalhão florecer, quando guiada pelo gênio desse perito artista; preza a Deos que a não vejamos morrer, hoje, que não brilha o seu pharol. Receba pois o Sr. Pedro Nolasco Baptista as sinceras e saudosas despedidas de nós, seus afeiçoados e admiradores do seu talento [...] (DIÁRIO DE PERNAMBUCO, 1852a).
\end{abstract}

Há, portanto, indícios fortes para acreditarmos que Pedro Nolasco Baptista residiu em Pernambuco entre os anos de 1850 e 1853 (e não no Rio de Janeiro, conforme sugerem os anúncios do Almanak Laemmert): estão entre eles o cargo de professor de música do Arsenal de Guerra (1850), a direção musical do 4 ㅇ batalhão d'artilharia a pé (1852), além de uma série de apresentações anotadas pela imprensa pernambucana entre os anos de 1851 e $1853 .^{3}$

A permanência em terras cariocas deve ter ocorrido, de fato, entre os anos de 1846 e 1850, quando não há quaisquer registros de sua presença em Recife. Talvez Nolasco tenha tentado a sorte na capital do império após ter perdido, em 1846, o posto de diretor musical de um dos batalhões pernambucanos e de não ter logrado o êxito que esperava como professor particular de música em sua terra natal.

3 A outra hipótese seria que o músico, neste período (1850-1853), tivesse se desdobrado em deslocamentos contínuos entre Recife e Rio de Janeiro, o que parece pouco provável pela natureza dos cargos militares que ocupou, que exigiam que ele ensinasse ou coordenasse ensaios duas vezes por semana, pelo menos. 
Sobre as atividades musicais exercidas no Rio de Janeiro, há poucas notícias. Além dos anúncios com a divulgação de suas aulas publicados no Jornal do Commercio (1846) e da inclusão de seu nome entre os professores de música do Almanak Laemmert (1847-1853), só coletamos o registro de duas apresentações do músico pernambucano nos palcos cariocas, ambas em benefício do trompista e professor Luiz José da Cunha e realizadas em julho de 1847 e abril de 1848, respectivamente (os detalhes se encontram no tópico sobre seus concertos).

De volta às origens, o músico passará a década de 1850 e parte da de 1860 realizando diversas apresentações como instrumentista, compositor e maestro nos principais teatros pernambucanos do período (Theatro de Apolo e Theatro de Santa Isabel), com destaque para os seus trabalhos como regente orquestral e diretor da banda de música militar do corpo de polícia.

Assim, durante cerca de 15 anos (1850-1865), Nolasco será um dos mais respeitados músicos atuantes em Pernambuco, com um reconhecimento que o levou, inclusive, a assumir postos importantes em localidades próximas. Em dezembro de 1861, o músico foi nomeado mestre das bandas de música do corpo de polícia e do Colégio de Educandos do Ceará, conforme expresso em portaria publicada na seção "Parte Oficial" do jornal O Cearense (1861), documento que o obrigava a dar pelo menos três lições semanais a cada uma das bandas, em um contrato de quatro meses com um salário mensal de 1508 réis.

De fato, nos dois anos iniciais da década de 1860, não há indicação de apresentações suas nos teatros de Pernambuco, o que reitera a perspectiva de que Nolasco estaria momentaneamente fora da cidade. Além disso, em abril de 1861, o jornal Pedro II, publicado em Fortaleza (capital da província cearense) e em Maranguape, anota a chegada do "hábil músico" à região, informando ainda que o mesmo pretendia dar um concerto e que não se demoraria muito por aquelas plagas. Note-se que seu prestígio o faz ser apresentado como "um artista nacional":

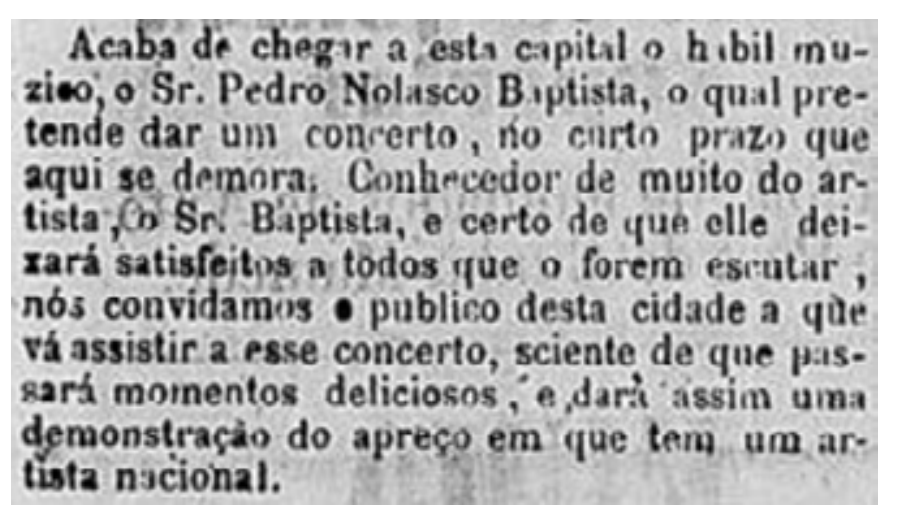

Fig. 2. Nota publicada no jornal Pedro II acusando a chegada de Nolasco no Ceará para realizar uma apresentação e passar uma curta temporada. Fonte: (PEDRO II, 1861).

A estada na região foi mesmo breve e o emprego na província do Ceará perdurou apenas até meados de 1862, quando a imprensa pernambucana volta a mencionar o seu nome dirigindo orquestras ou bandas de polícia em Recife, sua terra natal. Em junho daquele ano, os jornais nos deixam saber que Nolasco foi um dos passageiros do vapor 
nacional Jaguaribe, "advindo de Aracarú [Aracaju] e portos intermédios", naquele que marcaria o momento preciso de seu retorno a Pernambuco (DIÁRIO DE PERNAMBUCO, 1862a). A portaria publicada pelo jornal cearense Pedro II não somente corrobora a informação, mas também revela que as passagens do músico foram custeadas pelo estado (PEDRO II, 1862).

Definitivamente de volta a Pernambuco, o músico seguiu se apresentando como diretor de orquestra no Theatro de Santa Isabel até outubro de 1863, data do último registro de sua atuação artística como regente e/ou instrumentista nos periódicos investigados (DIÁRIO DE PERNAMBUCO, 1863a). Com a idade avançada e depois de mais de 30 anos atuando regularmente como músico, os problemas de saúde o impedem de seguir na carreira, conforme se depreende do concerto realizado em seu benefício ocorrido em julho de 1865, pouco antes de sua morte.

[...] O beneficiado achando-se impossibilitado de exercer a sua profissão há quase dous annos, aceitou o favor do digno emprezario, que de mui boa vontade lhe concedêra este espectaculo, e confiado na magnanimidade do respeitavel publico espera uma brilhante e numerosa concorrência, para ajuda do seu tratamento, e por isso desde já antecipa a todos os seus cordiaes agradecimentos (DIÁRIO DE PERNAMBUCO, 1865).

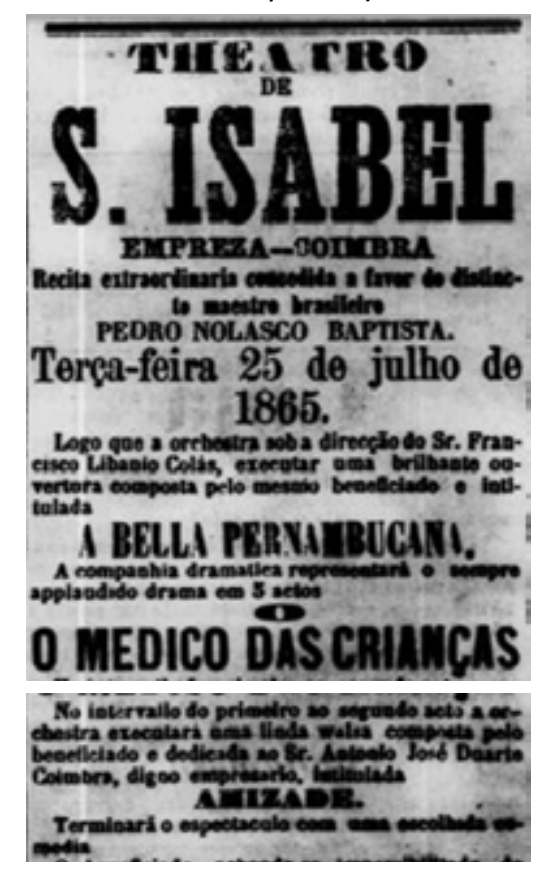

Fig. 3. Espetáculo em benefício de Pedro Nolasco Baptista oferecido pelo empresário Sr. Antonio José Duarte Coimbra para ajudá-lo com os tratamentos decorrentes dos problemas de saúde que o impediram de atuar nos últimos dois anos de sua vida. Fonte: (DIÁRIO DE PERNAMBUCO, 1865).

Embora o maestro estivesse impedido de atuar como regente, posto assumido pelo sr. Francisco Libanio Colás, note-se como, na ocasião, as duas peças executadas pela orquestra eram de sua autoria: a abertura A Bela Pernambucana; e a valsa Amizade, dedicada ao empresário e amigo Antonio Duarte, responsável por idealizar e organizar a apresentação em seu benefício no Theatro de Santa Isabel.

Esta noite seria o seu último canto como músico. Apesar dos esforços coletivos 
pela sua melhora, Nolasco só resistiria por mais três meses aos problemas de saúde, vindo a falecer no dia 24 de outubro de 1865. Os convites para as missas fúnebres de 30 dias por seu falecimento foram veiculados pelo jornal O Publicador (1865a; 1865b).

Conforme expressamos antes, aparentemente Nolasco não deixou herdeiros e tampouco há notícias de seu eventual contato com outros familiares. A missa em sua homenagem foi encomendada por um amigo e, apesar da significativa atuação musical por mais de três décadas (seja como compositor, maestro ou instrumentista), seu nome acabou obliterado pouco depois de sua morte.

A única menção referente a Nolasco que encontramos nos anos seguintes ao seu passamento ocorre em novembro de 1869, em passagem do jornal O Publicador na qual o músico é referido como "imortal" nas apresentações de sua Fantasia com Variações para oficleide e de um arranjo seu intitulado Alamiro e Belisário. O concerto foi dirimido pela sociedade musical da Paraíba, sob a direção musical de Pedro Joaquim de Alcântara César, por ocasião da celebração da festa anual de Santa Cecília.

A sociedade convida a todas as pessoas devotas, e amadoras de musica, a que compareção nestes actos nos quaes a exceção das Vesperas, todas as músicas de orchestra, e marcial que se tem de executar são novas, e ainda não vistas nesta cidade, chamando a attenção a Missa, e Te deum, peças de grande força e muito gosto, e marcial a fantasia com variações defficillimas para oficleide, composição do immortal Pedro Nolasco Baptista, e o duetto arranjado pelo mesmo: Alamiro e Belisario (O PUBLICADOR, 1869).

\section{Concertos, apresentações e benefícios}

Não é possível precisar a data em que Pedro Nolasco Baptista começou a atuar no cenário musical pernambucano. O Diário de Pernambuco, principal publicação a anotar suas atividades artísticas, passa a circular em 07 de novembro de 1825, mas apenas na década seguinte as primeiras notícias sobre o músico irão estampar as páginas do jornal. O que se sabe é que, já no início da década de 1830, Nolasco detinha o prestígio e reconhecimento necessários para motivar um espetáculo exclusivamente dedicado em seu benefício, articulando uma rede de contatos que englobava artistas tanto da música quanto do teatro.

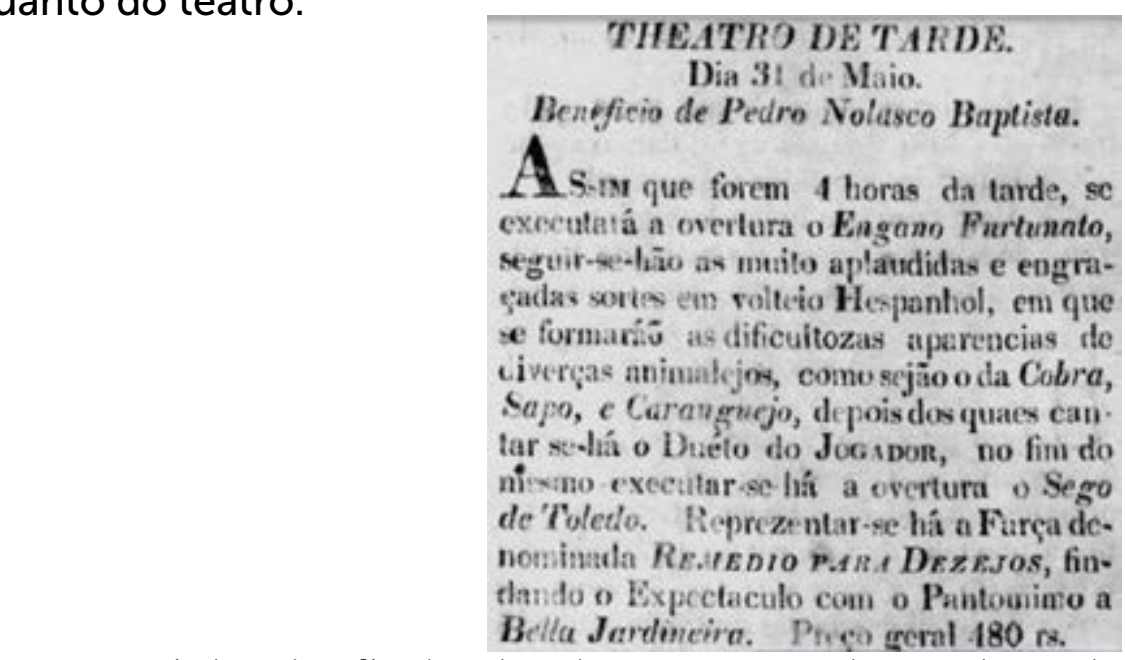

Fig. 4. Espetáculo em benefício de Pedro Nolasco Baptista ocorrido em 29 de maio de 1832, na programação vespertina do 
Como se observa, embora o espetáculo tenha sido realizado em favor de Nolasco, a sua participação artística no evento não é descrita na passagem. Apenas nove anos depois, em outubro de 1841, a sua condição de instrumentista e compositor é registrada em uma nova apresentação em seu benefício, quando o músico intercalará os atos da peça teatral representada na ocasião com números de flauta, oficleide (uma peça de sua autoria) e clarinete (este último executado por um de seus alunos).

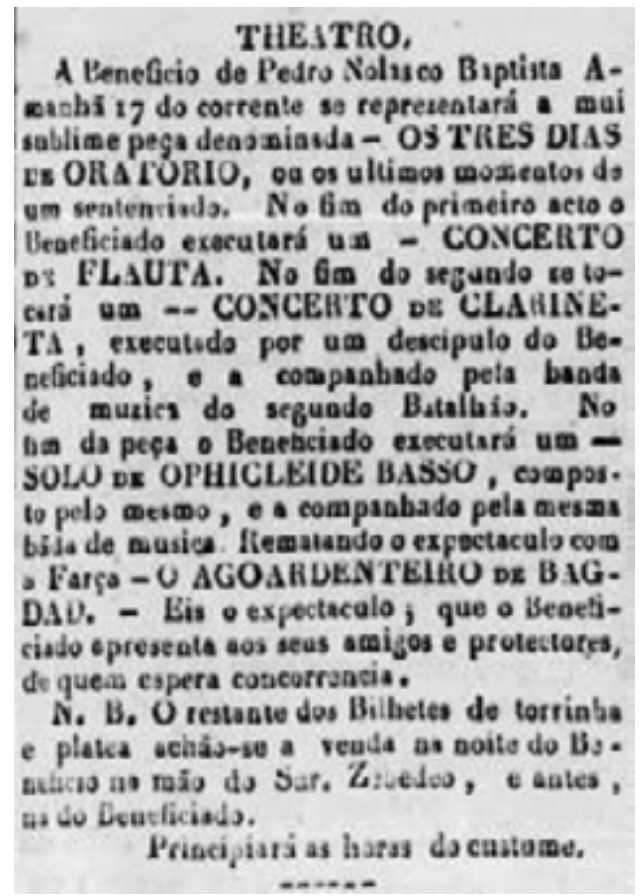

Fig. 5. Concerto em benefício de Pedro Nolasco Baptista em 16 de outubro de 1841, com números de flauta, clarinete e oficleide tocados pelo músico e um de seus alunos. Fonte: (DIÁRIO DE PERNAMBUCO, 1841).

Outra vez mostrando liderança e capacidade de aglutinar seus colegas artistas, Nolasco revela uma de suas mais decisivas atuações neste novo concerto em seu benefício: o domínio de variados instrumentos de sopro, condição que iria lhe ajudar sobremaneira como diretor, regente e professor de diversas bandas e orquestras militares, cargos que ocupou quase que ininterruptamente ao longo de sua carreira musical.

Entretanto, apesar de multi-instrumentista, o oficleide parece ter sido o seu instrumento de maior domínio, suposição que se sustenta através das diversas composições que lhe dedicou e pela significativa quantidade de vezes em que o pernambucano o executa nas apresentações que coletamos, chegando, inclusive, a ser intitulado pelo Jornal do Commercio (1847b) como o "1o ophicleid que tem apparecido no império". Silva corrobora a hipótese na seguinte passagem de seu livro:

É possivel que o oficleide, ou figle, fosse o instrumento predileto do Professor Pedro Nolasco Baptista por encontrarmos noticias suas desde 1851 tocando, nesse instrumento, diferentes peças de música, no teatro Apolo. Em 1853, tocou variações de sua autoria no teatro de Santa Isabel. Em 1862, apresentou de autoria própria a peça Represália, com variações, acompanhado de grande orquestra (SILVA, 2006: 212). 
Ainda na década de 1840, mais precisamente em novembro de 1845, o artista organizaria um terceiro evento em torno de si, voltando a protagonizar solos de flauta e oficleide (neste, tocou novamente uma composição sua), além de incluir variações de violão na terceira e última parte do programa. Apesar deste último instrumento figurar nos teatros pernambucanos desde o início da década de 1830, pelo menos, esta seria a primeira vez que um personagem de formação mais ampla e notório reconhecimento o empunhava publicamente naquela província.

THEATRO PUBLICO

QUINTA-FEIRA, 13 DE NOVEMBRO.

Funcção extraordinária lyrica, em beneficio de Pedro Nolasco Baptista, professor de musica, distribuída pela maneira seguinte:

1 Uma peça de musica pela banda militar do segundo batalhão.

2 Dueto da opera MARINO FALLIERO - se purglungi a trucidaria -, cantado pelos Srs. Franchi e Toselli.

3 Aria da opera LOMBARDI - como potes un'angalo -, cantada pelo Sr. Marinangeli. 4 Grande concerto de FLAUTA, executado pelo beneficiado.

Intervallo de 15 minutos.

1 Uma peça de musica pela mesma banda militar.

2. Dueto da opera NINA PAZZA PER AMORE - di qual voi non se cha farme -, cantado pela Sra Mariette e o Sr. José Marinangeli.

3 Variações ou fantasias de OPHICLEIDE, compostas pelo beneficiado, e dedicadas aos seus amigos.

Intervallo de 15 minutos.

1 Uma peça de musica pela mesma banda militar.

2 Variações de Violão ou guitarra franceza, executadas somente pelo beneficiado.

3 Aria da opera LINDA CHAMONNIX - o luco di que-t'anima -, cantada pela Sra. Marietta.

4 Dueto da opera COLUMELLA - quivi alberga il mio tesoro -, cantado pelos Srs. Franchi e Toselli.

O preço dos bilhetes de platéa e camarote regula o mesmo que os das representações de companhia italiana.

Principiará ás 8 horas.

(DIÁRIO DE PERNAMBUCO, 1845, grifos nossos)

Os espetáculos "em benefício" de alguém eram, de forma geral, apresentações variadas envolvendo, sobretudo, números musicais e teatrais (por vezes, números de dança e mesmo circenses eram acrescidos na programação). O esquema geralmente funcionava da seguinte forma: artistas ou grupos eram convidados a participar gratuitamente ou, em alguns casos, rateavam as bilheterias dos eventos (ou seja, excetuada a parte dos custos operacionais e a porcentagem do teatro, dividiam os eventuais lucros dos ingressos vendidos), enquanto o beneficiado era também agraciado com a benevolência espontânea dos presentes, o que, naturalmente, dependia não somente de uma boa relação com os pares e o público, mas também da qualidade e variedade de sua performance.

Por esta razão, era comum que os beneficiados apresentassem números variados, como no caso desta última apresentação de Nolasco, na qual o músico participou como compositor e executante de três distintos instrumentos: flauta, oficleide e violão. Após o espetáculo, geralmente o favorecido ia aos camarotes para recolher o dinheiro do público, que o oferecia espontaneamente e sem valores fixos, conforme se depreende 
da seguinte passagem do benefício realizado em favor do ator Francisco Salles Guimarães e Cunha, do qual Nolasco participou como regente da orquestra:

No fim do drama o artista, em cujo proveito se da esta recita, irá pelos camarotes receber aquillo, que the quizerem dar. $O$ actor Guimarães, conta ainda esta vez encontrar a benevolência e proteção de que o publico lhe tem dado tantas provas (DIÁRIO DE PERNAMBUCO, 1852C).

Os benefícios eram usualmente organizados por dois motivos: ora para celebrar talentos em ascensão, personalidades com destacado reconhecimento ou visitantes ilustres; ora para ajudar uma determinada instituição, grupo ou personagem (artista ou não) que apresentava alguma necessidade específica, algo que aconteceu com o próprio Nolasco no fim de sua carreira, na década de 1860, quando o músico enfrentou problemas de saúde que o impediam de trabalhar e, consequentemente, passava por sinuosas dificuldades financeiras. Foi também o caso do anão Roberto de Albuquerque Mello, que, por intermédio do presidente da província pernambucana, recebeu um recital beneficente da Sociedade Dramática Empresária, ocorrido em 27 de outubro de 1855, com apresentações teatrais e músicas compostas por Pedro Nolasco Baptista.

[...] He este o divertimento que o beneficiado pela primeira vez nesta província offerece ao respeitavel publico, a quem pede toda a proteção, visto a sua absoluta necessidade, pois que a natureza o privou de todos os recursos com que possa ganhar sua subsistência. Os bilhetes vendem-se no theatro. Principiará as 8 horas (DIÁRIO DE PERNAMBUCO, 1855).

Sobre a origem e o caráter dos benefícios, o pesquisador Antonio J. Augusto aponta que "esta forma de organização de concertos foi uma das mais utilizadas durante a primeira metade do século XIX, em lugares como Londres e Paris", acrescentando ainda que:

Esses concertos eram organizados pelos próprios músicos ${ }^{4}$ e possibilitavam, além do ganho material, a conquista de um espaço simbólico. Participar de um benefício de um renomado artista era uma maneira de ser reconhecido como músico de valor. De igual maneira, conseguir agregar músicos de destaque em um benefício próprio era uma forma de demonstrar seu prestígio entre seus pares.

Antonio Gonçalves ${ }^{5}$, em sua pesquisa sobre as transformações das práticas musicais do século XVIII para o século XIX, afirma que a maioria dos concertos de benefício não foi realizada por músicos mais necessitados, nem necessariamente pelos mais empreendedores, mas sim pelos principais intérpretes, por artistas que gozavam de prestígio e destaque por suas atuações nos teatros públicos e em concertos privados (AUGUSTO, 2014: 18).

\footnotetext{
$4 \quad$ Eventualmente também eram organizados por outros personagens da cadeia produtiva que girava em torno dos teatros, como artistas e/ou profissionais de outras áreas, empresários e mesmo políticos.

$5 \quad$ O autor indica a referência completa na qual se baseia: "GONÇALVES, A. J. (2011). Os concertos no tempo de Sor. Dissertação apresentada à Universidade de Aveiro para cumprimento dos requisitos necessários à obtenção do grau de Mestre em Música. Aveiro, Portugal: Departamento de Comunicação e Arte, p. 28" (AUGUSTO, 2014: 18).
} 
Portanto, a sequência de três benefícios em favor de Nolasco ocorridos entre as décadas de 1830 e 1840 nos dão uma possível dimensão do prestígio que o músico alcançara no cenário sociocultural da província pernambucana. No caso específico de Nolasco, esta importância é ratificada pelos cargos de direção musical que ocupou em corpos militares diversos.

Contudo, por razões desconhecidas, Nolasco foi desligado do posto de mestre de música do batalhão pernambucano que comandava em abril de 1846, passando, inicialmente, a oferecer aulas particulares em Recife para subsistir. Sem vínculo institucional e diante de um mercado regional que parecia não atender às suas expectativas como professor, o músico parte para tentar a sorte no Rio de Janeiro em junho de 1846, onde, como já observado no tópico anterior, muito provavelmente residiu até o ano de 1850. Neste período, através dos anúncios publicados no Almanak Laemmert e nos periódicos cariocas, sabe-se que Nolasco seguiu atuando no ensino particular de música (canto, violão e instrumentos de sopro). Além disso, o artista participou de pelo menos duas apresentações em benefício do trompista Luiz José da Cunha.

O primeiro deles ocorreu em 12 de julho de 1847, no Theatro de S. Pedro de Alcântara. O evento teve a participação de diversos artistas, inclusive contando com a estreia do pistonista, trompetista e compositor Henrique Alves de Mesquita (1830-1906), então com 17 anos, nos teatros do Rio de Janeiro. ${ }^{6} \mathrm{Na}$ divulgação do programa, publicado pelo Jornal do Commercio na véspera da apresentação, Nolasco foi descrito nos seguintes termos: "no fim da peça [o drama em 3 atos Clotilde], o sr. Pedro Nolasco Baptista, professor de musica, há pouco chegada a esta corte, executará umas brilhantes variações de - Guitarra franceza (violão)" (JORNAL DO COMMERCIO, 1847a).?

No dia seguinte, data do evento, a seção de correspondências do mesmo jornal (assinada por um leitor autodenominado "um apaixonado da música") volta a destacar a participação do músico pernambucano: "[...] temos de ouvir o Sr. Pedro Nolasco Baptista nas variações de violão; este senhor é um perfeito artista, e bem se póde dizer que, além de outros instrumentos que toca, é o 1o ophicleid que tem apparecido no império" (JORNAL DO COMMERCIO, 1847b).

Quase nove meses depois, no dia 10 de abril de 1848, Nolasco volta a participar de uma apresentação em favor do professor e trompista Luiz José da Cunha, desta vez no Theatro de São Francisco e executando no oficleide, ao lado do beneficiado (este no sax-horn), a adaptação de um dueto da ópera Marino Falieiro, do compositor italiano Gaetano Donizetti (1797-1848). (JORNAL DO COMMERCIO, 1848)

Nolasco retorna à terra natal em princípios da década de 1850 e, já em fevereiro de 1851, o Diário de Pernambuco anota sua reestreia nos palcos recifenses em grande

\footnotetext{
$6 \quad$ Sobre este importante personagem da música brasileira do século XIX, conferir: AUGUSTO, A. J. Henrique Alves de Mesquita: da pérola mais luminosa à poeira do esquecimento. Rio de Janeiro: Folha Seca, 2014.

7 Esta apresentação já havia sido registrada nos trabalhos de Taborda (2004: 58), Silva (2006: 112) e Augusto (2014: 15).

8 No anúncio da programação, uma nota adenda do trompista Luiz José da Cunha nos dá uma dimensão precisa de como, por vezes, os benefícios eram utilizados para socorrer os artistas em eventuais necessidades: "O beneficiado, tendo sofrido revezes e perdas não premeditadas, vê-se na necessidade de lançar mão deste recurso, supplicando aos seus amigos e ao respeitavel publico sua respeitavel e almejada proteção. Baldo de talentos, protesta esforçar-se pelo bom desempenho de sua supplica" (JORNAL DO COMMERCIO, 1848).
} 
estilo, participando dos espetáculos promovidos em torno da célebre cantora italiana Augusta Candiani (1820-1890), artista radicada no Rio de Janeiro desde 1844 e possivelmente a cantatriz que atingiu maior repercussão em solo brasileiro durante o II Reinado (1840-1889).

Contratada para uma série de espetáculos no Theatro de Apolo, a estrela - que encantara o escritor Machado de Assis e o imperador D. Pedro II - destilou seu talento em terras pernambucanas cantando modinhas e árias operísticas de diversos compositores, sendo acompanhada na flauta ou no oficleide, em algumas delas, pelo "mui distinto artista pernambucano, o Sr. Pedro Nolasco Baptista" (DIÁRIO DE PERNAMBUCO, 1851). Isto demonstra que, a par dos anos que havia passado no Rio de Janeiro, Nolasco preservava, em seu berço, o prestígio galgado nas duas décadas anteriores.

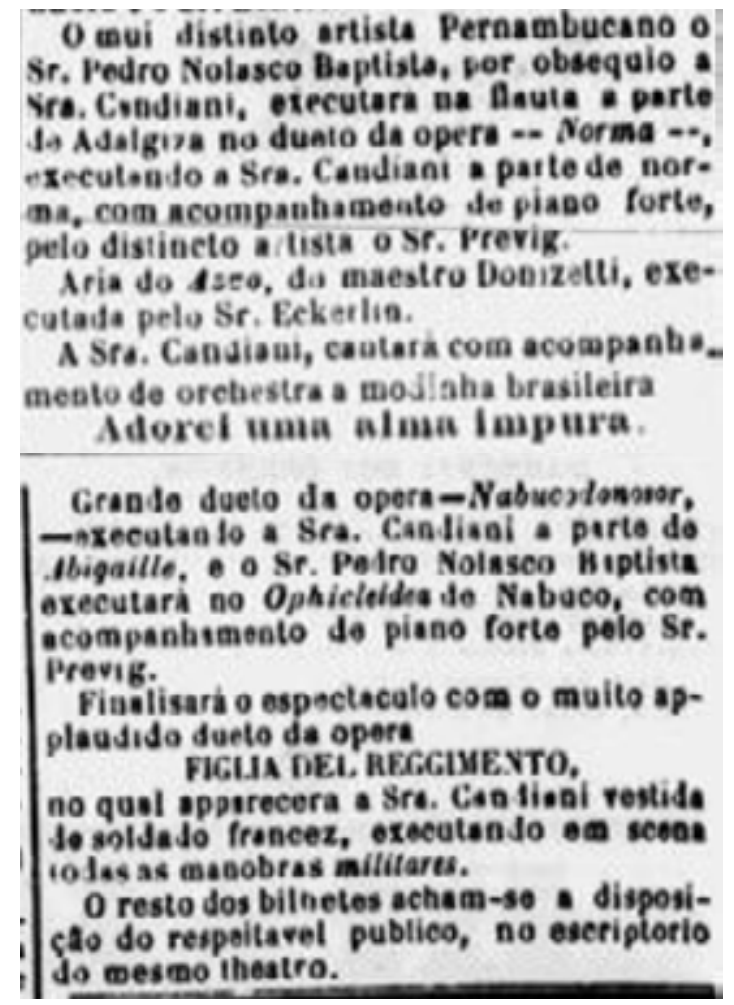

Fig. 6. Excerto do programa de uma das apresentações da cantora italiana Augusta Candiani no Theatro de Apolo, Pernambuco, em 07 de fevereiro de 1851, sendo acompanhada em alguns números por Pedro Nolasco Baptista na flauta ou no oficleide. Fonte: (DIÁRIO DE PERNAMBUCO, 1851).

O concerto com Candiani foi apenas a fagulha de uma década marcada por intensa atividade artística de Nolasco. Já em abril de 1852, o músico volta a participar de um concerto em benefício ("recita extraordinária"), desta vez em favor do pintor cenográfico Eduardo Claudino Corrêa Cabral. Na ocasião, não somente executou no "baixo de harmonia belíssimas e difíceis variações a seu capricho", mas também se apresentou como regente da "grande orquestra" responsável por abrir a noite com uma "brilhante ouverture" (DIÁRIO DE PERNAMBUCO, 1852b).

A partir de então, o seu trabalho como regente (e por vezes como compositor e/ou intérprete) irá dominar a cena musical pernambucana ao longo dos cinco anos seguintes, com mais de uma dezena de distintas apresentações registradas pelos jornais 
da região. O momento marca, indubitavelmente, o auge de sua carreira artística e a Tab. 1 revela como este período foi, de fato, o mais prolífico de sua trajetória.

Dentre os 20 anúncios que citam as atividades musicais de Nolasco entre as décadas de 1830 e 1860, basta frisar que 13 deles estão concentrados no ínterim compreendido entre 1851 e 1857. Vale pontuar, ainda, que o número real de suas apresentações é seguramente maior, uma vez que coletamos outros espetáculos levados a cabo nos mesmos teatros e protagonizados pelos mesmos corpos artísticos que, todavia, não citam nominalmente os regentes atuantes nas ocasiões (muito provavelmente Pedro Nolasco Baptista).

\begin{tabular}{|c|c|c|c|c|}
\hline Local & Benefício & Data & Função/Repertório & Fonte \\
\hline $\begin{array}{l}\text { Theatro } \\
\text { da Tarde } \\
\text { (PE) }\end{array}$ & $\begin{array}{c}\text { do próprio } \\
\text { Pedro Nolasco Baptista }\end{array}$ & $\begin{array}{c}1832 \\
31 \text { de maio }\end{array}$ & [sem descrição] & $\begin{array}{c}\text { Diário de Pernambuco } \\
\text { (1832) }\end{array}$ \\
\hline Theatro (PE) & $\begin{array}{c}\text { do próprio } \\
\text { Pedro Nolasco Baptista }\end{array}$ & $\begin{array}{c}1841 \\
16 \text { de novembro }\end{array}$ & $\begin{array}{c}\text { Compositor e instrumentis- } \\
\text { ta/ flauta, oficleide-baixo, } \\
\text { clarineta }\end{array}$ & $\begin{array}{c}\text { Diário de Pernambuco } \\
\text { (1841) }\end{array}$ \\
\hline $\begin{array}{c}\text { Theatro } \\
\text { Público (PE) }\end{array}$ & $\begin{array}{c}\text { do próprio } \\
\text { Pedro Nolasco Baptista }\end{array}$ & $\begin{array}{c}1845 \\
13 \text { de novembro }\end{array}$ & $\begin{array}{l}\text { Compositor e instrumentis- } \\
\text { ta/ flauta, oficleide e violão }\end{array}$ & $\begin{array}{c}\text { Diário de Pernambuco } \\
(1845) \\
\end{array}$ \\
\hline $\begin{array}{l}\text { Theatro São } \\
\text { P. de Alcân- } \\
\text { tara (RJ) }\end{array}$ & $\begin{array}{c}\text { do trompista } \\
\text { Luiz José da Cunha }\end{array}$ & $\begin{array}{c}1847 \\
12 \text { de julho }\end{array}$ & $\begin{array}{l}\text { Guitarra francesa (violão)/ } \\
\text { "brilhantes variações" }\end{array}$ & $\begin{array}{l}\text { Jornal do Commercio } \\
\text { (1847a) }\end{array}$ \\
\hline $\begin{array}{l}\text { Theatro de } \\
\text { São Francis- } \\
\text { co (RJ) }\end{array}$ & $\begin{array}{l}\text { do trompista } \\
\text { Luiz José da Cunha }\end{array}$ & $\begin{array}{c}1848 \\
10 \text { de abril }\end{array}$ & $\begin{array}{l}\text { Oficleide/ dueto da ópera } \\
\text { Marino-Falieiro }\end{array}$ & $\begin{array}{l}\text { Jornal do Commercio } \\
\qquad(1848)\end{array}$ \\
\hline $\begin{array}{l}\text { Theatro de } \\
\text { Apollo (PE) }\end{array}$ & $\begin{array}{l}\text { da cantora italiana } \\
\text { Augusta Candiani }\end{array}$ & $\begin{array}{c}1851 \\
07 \text { de fevereiro }\end{array}$ & $\begin{array}{c}\text { Acompanhamentos na flauta } \\
\text { e no oficleide }\end{array}$ & $\begin{array}{c}\text { Diário de Pernambuco } \\
\text { (1851) } \\
\end{array}$ \\
\hline $\begin{array}{l}\text { Theatro de } \\
\text { Apollo (PE) }\end{array}$ & $\begin{array}{c}\text { do pintor cenográfico } \\
\text { Eduardo Claudino } \mathrm{C} . \\
\text { Cabral }\end{array}$ & $\begin{array}{c}1852 \\
03 \text { de abril }\end{array}$ & $\begin{array}{l}\text { Regente orquestral/ "bri- } \\
\text { lhante ouvertura" }\end{array}$ & $\begin{array}{c}\text { Diário de Pernambuco } \\
\text { (1852b) }\end{array}$ \\
\hline $\begin{array}{l}\text { Theatro de } \\
\text { Apollo (PE) }\end{array}$ & $\begin{array}{c}\text { do ator Francisco de } \\
\text { Salles Guimarães e } \\
\text { Cunha }\end{array}$ & $\begin{array}{c}1852 \\
15 \text { de abril }\end{array}$ & $\begin{array}{l}\text { Regente orquestral/ "bri- } \\
\text { lhante ouvertura" }\end{array}$ & $\begin{array}{c}\text { Diário de Pernambuco } \\
(1852 \mathrm{c})\end{array}$ \\
\hline $\begin{array}{l}\text { Theatro de } \\
\text { Santa Isabel } \\
\text { (PE) }\end{array}$ & $\begin{array}{l}\text { na estreia do ator João } \\
\text { Antonio da Costa }\end{array}$ & $\begin{array}{c}1852 \\
21 \text { de agosto }\end{array}$ & $\begin{array}{l}\text { Regente e compositor/ "bri- } \\
\text { lhante ouvertura" }\end{array}$ & $\begin{array}{l}\text { Diário de Pernambuco } \\
\text { (1852d) }\end{array}$ \\
\hline $\begin{array}{l}\text { Theatro de } \\
\text { Santa Isabel } \\
\text { (PE) }\end{array}$ & "recita extraordinária" & $\begin{array}{c}1855 \\
02 \text { de junho }\end{array}$ & $\begin{array}{c}\text { Regente orquestral/ "A Bata- } \\
\text { lha de Badajoz"9 }\end{array}$ & $\begin{array}{c}\text { Diário de Pernambuco } \\
\text { (1853) }\end{array}$ \\
\hline $\begin{array}{l}\text { Theatro de } \\
\text { Santa Isabel } \\
\text { (PE) }\end{array}$ & $\begin{array}{l}\text { do anão Roberto de } \\
\text { Albuquerque Mello }\end{array}$ & $\begin{array}{c}1856 \\
27 \text { de outubro }\end{array}$ & $\begin{array}{c}\text { "a música é composição do } \\
\text { sr. P. N. Baptista" }\end{array}$ & $\begin{array}{c}\text { Diário de Pernambuco } \\
\text { (1855) }\end{array}$ \\
\hline $\begin{array}{l}\text { Theatro de } \\
\text { Santa Isabel } \\
\text { (PE) }\end{array}$ & $\begin{array}{c}\text { dos estudantes de } \\
\text { Direito, pela artista Anna } \\
\text { Girardot }\end{array}$ & $\begin{array}{c}1856 \\
27 \text { de agosto }\end{array}$ & $\begin{array}{l}\text { Instrumentista/ oficleide } \\
\text { ( } 2 \text { números em acomp.) }\end{array}$ & $\begin{array}{c}\text { Diário de Pernambuco } \\
(1856 a)\end{array}$ \\
\hline
\end{tabular}




\begin{tabular}{|c|c|c|c|c|}
\hline $\begin{array}{l}\text { Theatro de } \\
\text { Santa Isabel } \\
\text { (PE) }\end{array}$ & do ator sr. Santa Rosa & $\begin{array}{c}1856 \\
6 \text { de novembro }\end{array}$ & $\begin{array}{c}\text { Regente da banda militar do } \\
\text { corpo da polícia/ Sinfonia "A } \\
\text { Marquesa"10 }\end{array}$ & $\begin{array}{l}\text { Diário de Pernambuco } \\
\text { (1856b) }\end{array}$ \\
\hline $\begin{array}{l}\text { Theatro de } \\
\text { Santa Isabel } \\
\text { (PE) }\end{array}$ & $\begin{array}{l}\text { da sra. Florinda Knoth, } \\
\text { organizado pelo ator } \\
\text { Santa Rosa }\end{array}$ & $\begin{array}{c}1856 \\
27 \text { de novembro }\end{array}$ & $\begin{array}{l}\text { Regente da banda militar do } \\
\text { corpo da polícia/ "ouvertu- } \\
\text { ra"11 }\end{array}$ & $\begin{array}{l}\text { Liberal Pernambucano } \\
\qquad(1856 a)^{12}\end{array}$ \\
\hline $\begin{array}{l}\text { Theatro de } \\
\text { Santa Isabel } \\
\text { (PE) }\end{array}$ & $\begin{array}{l}\text { espetáculo } \\
\text { do sr. Sa }\end{array}$ & $\begin{array}{c}1856 \\
02 \text { de dezembro }\end{array}$ & $\begin{array}{c}\text { Regente Orquestral/ hino } \\
\text { nacional }\end{array}$ & $\begin{array}{r}\text { Liberal Pern } \\
\qquad(185\end{array}$ \\
\hline $\begin{array}{l}\text { Theatro de } \\
\text { Santa Isabel } \\
\text { (PE) }\end{array}$ & $\begin{array}{c}\text { último espetáculo sob a } \\
\text { direção do artista Santa } \\
\text { Rosa }\end{array}$ & $\begin{array}{c}1856 \\
13 \text { de dezembro }\end{array}$ & egênc & $\begin{array}{r}\text { Liberal Pe } \\
(18\end{array}$ \\
\hline $\begin{array}{l}\text { Theatro de } \\
\text { Santa Isabel } \\
\text { (PE) }\end{array}$ & $\begin{array}{l}\text { do sr. Julio e do ator Re- } \\
\text { zende, concedido pelo } \\
\text { presidente da província }\end{array}$ & $\begin{array}{c}1857 \\
22 \text { de janeiro }\end{array}$ & $\begin{array}{c}\text { Regente da banda militar do } \\
\text { corpo da polícia/ "O Cavalo } \\
\text { de Bronze"15 }\end{array}$ & $\begin{array}{l}\text { Diário de Pernambuco } \\
\text { (1857a) }\end{array}$ \\
\hline $\begin{array}{l}\text { Theatro de } \\
\text { Santa Isabel } \\
\text { (PE) }\end{array}$ & $\begin{array}{c}\text { do ator Santa Rosa. últi- } \\
\text { mo recita da Sociedade } \\
\text { Dramática Empresária }\end{array}$ & $\begin{array}{c}1857 \\
19 \text { de agosto }\end{array}$ & $\begin{array}{c}\text { Regente orquestral/ "A Bata- } \\
\text { Iha de Badajoz" }\end{array}$ & $\begin{array}{r}\text { Diário de } \mathrm{P} \\
\qquad(185\end{array}$ \\
\hline $\begin{array}{l}\text { Theatro } \\
\text { (CE) }\end{array}$ & ? & 18 & $?$ & $\begin{array}{c}\text { Jornal Pedro II } \\
\text { (1861) }\end{array}$ \\
\hline $\begin{array}{l}\text { Theatro de } \\
\text { Santa Isabel } \\
\text { (PE) }\end{array}$ & $\begin{array}{c}\text { do Hospital Português } \\
\text { de Beneficência, por } \\
\text { Pedro Baptista de Santa } \\
\text { Rosa } \\
\end{array}$ & $\begin{array}{c}1862 \\
22 \text { de outubro }\end{array}$ & $\begin{array}{l}\text { Regente orquestral/ "O Con- } \\
\text { de d'Essex, de Mercadanti" }\end{array}$ & $\begin{array}{l}\text { Diário de Pernambuco } \\
\text { (1862b) }\end{array}$ \\
\hline $\begin{array}{c}\text { Theatro de } \\
\text { Santa Isabel } \\
\text { (PE) }\end{array}$ & $\begin{array}{l}\text { do próprio Pedro Nolas- } \\
\text { co Baptista: "Concerto } \\
\text { Especial de Música" } \\
\end{array}$ & $\begin{array}{c}1862 \\
17 \text { de dezembro }\end{array}$ & $\begin{array}{c}\text { Regente, camerista, ins- } \\
\text { trumentista/ fantasias para } \\
\text { oficleide }\end{array}$ & $\begin{array}{r}\text { Diário de } \mathrm{P} \\
(18\end{array}$ \\
\hline $\begin{array}{l}\text { Theatro de } \\
\text { Santa Isabel } \\
\text { (PE) }\end{array}$ & $\begin{array}{c}\text { da atriz Camilla Moreira } \\
\text { Guimarães }\end{array}$ & $\begin{array}{c}1863 \\
05 \text { de agosto }\end{array}$ & $\begin{array}{c}\text { Regente orquestral/ } \\
\text { ouvertura Marco Spada } \\
\text { " }\end{array}$ & $\begin{array}{l}\text { Diário de Pernambuco } \\
\text { (1863b) }\end{array}$ \\
\hline $\begin{array}{l}\text { Theatro de } \\
\text { Santa Isabel } \\
\text { (PE) }\end{array}$ & $\begin{array}{l}\text { do ator Antonio José } \\
\text { Peixoto Guimarães }\end{array}$ & $\begin{array}{c}1863 \\
28 \text { de outubro }\end{array}$ & $\begin{array}{c}\text { Oficleide/ } \\
\text { "uma Cavatina" }\end{array}$ & $\begin{array}{c}\text { Diário de Pernambuco } \\
\text { (1863a) }\end{array}$ \\
\hline $\begin{array}{c}\text { Theatro de } \\
\text { Santa Isabel } \\
\text { (PE) }\end{array}$ & $\begin{array}{l}\text { "Em favor do distinto } \\
\text { maestro brasileiro Pedro } \\
\text { Nolasco Baptista" }\end{array}$ & $\begin{array}{c}1865 \\
25 \text { de julho }\end{array}$ & $\begin{array}{c}\text { Compositor/ ouvertura "A } \\
\text { Bela Pernambucana"; valsa } \\
\text { "Amizade" }\end{array}$ & $\begin{array}{l}\text { Diário de Pernambuco } \\
\text { (1865) }\end{array}$ \\
\hline
\end{tabular}

Tab. 1. Vinte e quatro apresentações de Pedro Nolasco Baptista nos teatros pernambucanos, cariocas e cearenses registradas pela imprensa entre as décadas de 1830 e 1860. Fonte: elaboração do autor.

9 Na descrição do programa, a peça dirigida por Nolasco é referenciada da seguinte maneira: "A pedido de muitas pessoas, propoz-se o Sr. Pedro Nolasco Baptista, director da orchestra, a fazer executar a interessante peça de música, que acima fica declarada [A Batalha de Badajoz], na qual haverão os toques seguintes: - introdução, chamada de officiaes, marcha em continência, avançada, ataque de batalha, alegro, fogo e degolar, toque de arrebate, tiros de peça, [ilegível], ataque de fogo: segue um alegro correspondente, cessar fogo, adagio, gemidos dos feridos, reunir, alegro em retirada, valsa victoria" (DIÁRIO DE PERNAMBUCO, 1853).

10 A nota de divulgação do programa acrescenta que: "[...] os intervalos serão preenchidos com as melhores peças de musica de repertório do dito Sr. Pedro Nolasco, e entre as quaes executarão o novo terceto da opera MARCO VISCONTI, e um dueto da mesma opera, tambem novo" (DIÁRIO DE PERNAMBUCO, 1856b).

11 "As melhores" peças do repertório de Nolasco voltam a preencher os intervalos deste novo concerto beneficente, dentre as quais constavam "(a pedido de muitas pessoas), O MISERERE, aria da opera O Trovador" (DIÁRIO DE PERAMBUCO, 1856c).

12 O evento também foi noticiado no jornal Diário de Pernambuco (1856c).

13 O evento também foi noticiado no jornal Diário de Pernambuco (1856d).

14 O evento também foi noticiado no jornal Diário de Pernambuco (1856e).

15 Nos intervalos do drama brasileiro apresentado - A Cigana Brasileira -, voltou a figurar o repertório de Nolasco: "[...] os intervalos serão preenchidos com as melhores peças de musica do repertório do insigne artista o Sr. Pedro Nolasco Baptista" (DIÁRIO DE PERNAMBUCO, 1857a).

16 O evento também foi noticiado no jornal Diário de Pernambuco (1857b). 
Como se nota, entre os cinco anos que permeiam agosto de 1857 e outubro de 1862, não há registros nominais de apresentações suas nos teatros pernambucanos, embora, como já destacamos, seja possível que o músico tenha participado de outros eventos neste interstício, uma vez que os nomes dos artistas participantes nem sempre eram creditados nos anúncios de espetáculos do gênero.

O que se sabe é que, a partir de dezembro de 1861, o músico passou uma temporada de quatro meses no Ceará, nomeado pelo presidente da província como diretor e mestre das bandas de música do corpo de polícia e do Colégio de Educandos (O CEARENSE, 1861). Na breve passagem por Fortaleza, Nolasco provavelmente também se apresentou nos teatros locais, conforme indica o seguinte trecho publicado no jornal cearense Pedro II (1861): "Acaba de chegar a esta capital o hábil músico, o Sr. Pedro Nolasco Baptista, o qual pretende dar um concerto no curto prazo que aqui se demora".

Em meados de 1862, porém, o músico já havia regressado à terra natal, voltando a reger orquestras e a participar como instrumentista em concertos beneficentes. Neste mesmo ano, Nolasco irá organizar, no Theatro de Santa Isabel, aquela que talvez tenha sido a mais grandiosa apresentação de sua carreira. Ocorrido em 17 de dezembro de 1862, o evento foi assim descrito na nota introdutória que acompanhava a divulgação da programação: "O professor de música Pedro Nolasco Baptista, bem conhecido nesta província, resolveu oferecer aos amadores da boa musica em particular, e ao publico em geral, um concerto especial, para o que se não poupou á fadigas, conseguindo reunir os principais artistas, seus irmãos d'arte [...]" (JORNAL DE PERNAMBUCO, 1862c). Merecem destaque as letras garrafais com as quais o título do evento foi anunciado, algo pouco comum para os anúncios do período:

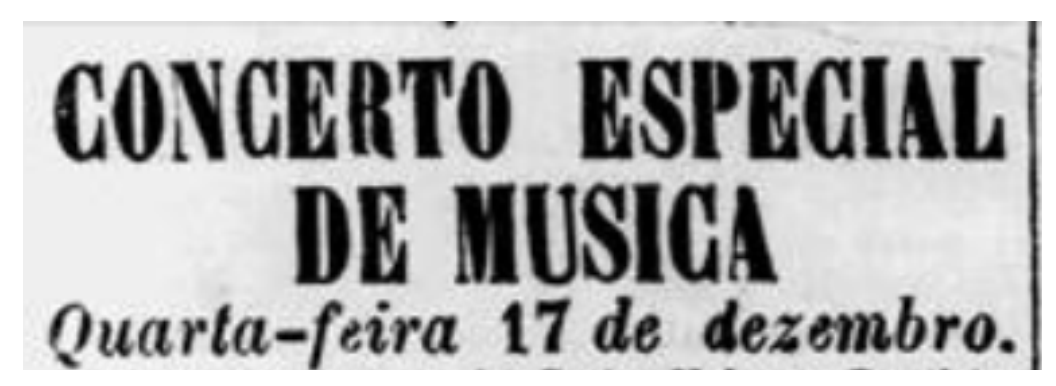

Fig. 7. Concerto dirimido por Pedro Nolasco Baptista em 17 de dezembro de 1862, no Theatro de Santa Isabel. Reprodução do tamanho original publicado no jornal. Fonte: (DIÁRIO DE PERNAMBUCO, 1862c).

O programa do grande evento foi dividido em três partes e reuniu uma gama impressionante de músicos: os corpos da orquestra do teatro e das bandas do $7^{\circ}$ e do 9 batalhões de infantaria de linha, além de outros convidados que tocaram piano, flauta e oficleide (em solo, câmera ou com orquestra). Além de organizar e produzir o espetáculo, Nolasco participou da apresentação tocando três fantasias para oficleide de sua autoria, cada uma delas executada em partes específicas da programação, sendo a última "composta e especialmente dedicada aos seus amigos e apreciadores". O músico também integrou um pequeno terceto de oficleides ao lado dos professores Dimas e Felippe e, encerrando a noite, regeu "o bello galope do Caminho de ferro, [tocado] pelas 
duas bandas militares, ensaiadas pelo beneficiado" (DIÁRIO DE PERNAMBUCO, 1862c). ${ }^{17}$ Silva transcreve uma crítica publicada no Diário de Pernambuco referente ao concerto, na qual se diz que Nolasco, empunhando o seu oficleide, atingiu momentos sublimes na apresentação, fazendo jus à arte que abraçara desde tenra idade:

Teve lugar na noite de quarta-feira um concerto especial em benefício do artista Pedro Nolasco Baptista, no qual tomaram parte diversos companheiros que executaram bellos pedaços do seu repertório. O Sr. Pedro Baptista mais uma vez patenteou o gosto e o esmero com a arte que abraçou desde bem jovem, e por mais uma vez, nessa noite, esteve sublime, porquanto cada nota desprendida do seu ophicleyde era uma nova expressão animadora e arrebatadora. (apud SILVA,

2006: 213).

De fato, o sucesso do evento e a mobilização e ajuda dos colegas de profissão convocados foram tamanhos que motivaram uma extensa nota de gratidão assinada por Nolasco, publicada no Diário de Pernambuco em 22 de dezembro de 1862, cinco dias após a realização do concerto.

GRATIDÃO. Ajudado no concerto, que acabo de dar no theatro de Santa Isabel, pelo concurso de vários companheiros de arte, não devo faltar á uma publica manifestação de reconhecimento a esta prova de sympahtia, de que fui objecto desses que com a pericia que lhes é propria, mais abrilhantaram aquelle serão musical, e me proporcionaram meios de satisfazer áquella publica expectativa.

É este o meu [ilegível] nestas palavras, que ora venho consignar a publicidade; e para mais perpetuar a minha gratidão, peço licença a esses companheiros d'arte para declarar aqui alguns dos seus nomes como um penhor desta minha gratidão, que jamais perderá força ao nome dos Srs. Smoltz, maestro de musica, que se dignou reger a orchestra, Jorge Victor Junior, Salustiano Libanio Tenorio e Antero de tal contramestre da banda do 9 ㅇaㄹalhão, que tomaram parte no concerto, tocando estes na flauta, e o outro no piano, em que são completamente apreciados pelo publico desta cidade.

Estas minhas palavras estendem-se igualmente aos mais professores da orchestra em geral, e ao pessoal das bandas de musica do $7^{\circ}$ e 9 ㅇ batalhão de linha, cujos mestres se prestaram gratuitamente a obsequiar-me com os seus esforços e boa vontade.

Consignando o facto, porem, longe está de mim a intenção de livrar-me da gratidão que devo, e que me orgulho de manifestar. Em mim sempre terão elles um obsequiado reconhecido, e que jamais faltará aos deveres que lhe são próprios, dignando-se todos estes senhores de aceitar esta expressão do amigo penhorado. Pedro Nolasco Baptista (DIÁRIO DE PERNAMBUCO, 1862d).

Depois deste emblemático concerto, Nolasco ainda realizaria outras duas apresentações no Theatro de Santa Isabel durante o ano de 1863: a primeira em 05 de agosto, em benefício da atriz Camilla Moreira Guimarães, quando o músico abriu o espetáculo regendo a

\footnotetext{
17 Esta apresentação já havia sido mencionado por Silva, que, ao comentá-la, sugere: "Pela data da realização, teria sido um concerto de Natal, tal como acontece nos dias atuais, quando se procura reunir à Orquestra Sinfônica, algumas bandas civis e militares, para a realização de pomposos recitais públicos, ou mesmo com corais de certa de 150 cantores, onde cinquenta talvez, cantem e os demais são meros figurantes para um pose fotográfica e ainda ajudem para uma boa gritaria" (2006: 212-213).
} 
orquestra com uma ouverture (DIÁRIO DE PERNAMBUCO, 1863b); e uma posterior em 28 de outubro, data em que os jornais pernambucanos registram a sua última atuação como instrumentista, ao tocar, em seu oficleide, uma cavatina no espetáculo em favor do ator Antonio José Peixoto Guimarães (DIÁRIO DE PERNAMBUCO, 1863a).

Nos dois anos seguintes, problemas de saúde o impedem de seguir atuante e suas atividades musicais passam a ficar forçosamente limitadas. As dificuldades físicas logo se convertem também em dificuldades financeiras, a tal ponto que, pouco antes de sua morte, o empresário e amigo Antonio José Duarte Coimbra organiza um último concerto "para ajuda do seu tratamento", ocorrido em 25 de julho de 1865 . Em seu canto do cisne, Nolasco teve uma atuação dupla como compositor: com a abertura $A$ Bela Pernambucana e a valsa Amizade (DIÁRIO DE PERNAMBUCO, 1865). Seu falecimento ocorre no dia 24 de outubro de 1865, cerca de três meses depois dos últimos esforços empenhados - por ele e seus colegas artistas - na preservação de sua vida.

Desde então, a par de sua significativa participação na prática e ensino de música em Pernambuco entre as décadas de 1830 e 1860, sua trajetória e contribuição permaneceram praticamente desconhecidas pela musicologia brasileira, uma lacuna que, em parte, 0 presente artigo pretende contornar, abrindo portas para futuras e necessárias pesquisas e aprofundamentos (suas composições, por exemplo, trariam novas luzes ao tema se eventualmente descobertas).

\section{Considerações finais}

Nos anos oitocentos, muito pouco se sabe sobre os músicos nordestinos que atuaram em províncias brasileiras diversas da corte do Rio de Janeiro, então capital do império, especialmente aqueles cuja trajetória de vida pertence (total ou majoritariamente) à primeira metade do século. Pernambuco não é uma exceção: no período em questão, quase nada se conhece sobre os personagens musicais que atuaram na região.

As dezenas de fontes levantadas nos periódicos brasileiros oitocentistas indicam que Pedro Nolasco Baptista foi um dos mais atuantes músicos pernambucanos entre as décadas de 1830 e 1860. Nenhum de seus contemporâneos motivou tantas notícias e alcançou tanta repercussão quanto ele na imprensa local, a qual, em diversos momentos, o classificou de "grande", "insigne", "hábil", "gênio", "perito artista", e assim por diante.

O prestígio alcançado pelo músico na sociedade pernambucana também pode ser dimensionado a partir de sua presença em momentos pontuais da vida política e sociocultural da província. Quando, por exemplo, foi convocada uma comissão encarregada pelas honras fúnebres de D. Maria II (1819-1853), a filha mais velha de D. Pedro l, o músico foi um de seus seletos participantes. Entre os seus membros, constavam a nata das classes política, militar, jurídica, religiosa, comercial e civil de Pernambuco (O LIBERAL PERNAMBUCANO, 1854).

Sobre sua condição financeira, o músico parece ter intercalado momentos tranquilos e difíceis. No auge da carreira, conquistou algumas significativas remunerações como diretor de orquestras/bandas e professor de colégios ou corpos militares/policiais. Abaixo, a Tab. 2 apresenta a descrição de alguns dos salários recebidos em relação aos respectivos ofícios que desempenhou. 


\begin{tabular}{|c|c|c|c|}
\hline Data & Ofício & Salário & Localidade \\
\hline $1836 /$ abril & Contramestre de Música & $127 \$ 470$ reis (pagamento único) & Jacuípe \\
\hline $1850 /$ maio & $\begin{array}{c}\text { Professor de música do } \\
\text { Arsenal de Guerra }\end{array}$ & $40 \$ 000$ reis anuais \\
\hline c. 1851/1852 & $\begin{array}{c}\text { Diretor musical do 4o ba- } \\
\text { talhão d'artilharia a pé }\end{array}$ & $\begin{array}{c}\text { alta gratificação por "seu bem co- } \\
\text { nhecido mérito" }\end{array}$ & Recife \\
\hline $1861 /$ dezembro & $\begin{array}{c}\text { Diretor e mestre das } \\
\text { bandas de mús. do corpo } \\
\text { de polícia e do Colégio de } \\
\text { Educandos }\end{array}$ & $\begin{array}{c}1508 \text { réis mensais } \\
\text { (por 4 meses) }\end{array}$ & Fortaleza \\
\hline
\end{tabular}

Tab. 2. Salários recebidos por Pedro Nolasco Baptista em diferentes momentos de sua carreira.

Fonte: elaboração do autor.

Nolasco ocupou ainda outros cargos similares como maestro, diretor ou professor institucional, mas os apontados na Tab. 2 são os únicos que revelam os valores pecuniários recebidos. Em seus melhores momentos, chegou a ter uma condição que lhe permitia sustentar uma vida com escravos. Em 1846, quando foi desligado do cargo de mestre de música do batalhão pernambucano que comandava e logo depois se mudou para o Rio de Janeiro, a imprensa da época nos revela que o músico se desfez de uma escrava crioula chamada Maria.

-- Fugio, na noite do dia 10 do corrente [agosto de 1846], uma escrava, de nome Maria, de altura regular, côr fula, beiços grossos, com uma marca preta em cima do peito, e está pejada; levou dous vestidos de chita novos, panno fino preto, e outra da Costa. Esta escrava parece crioula, por ter vindo pequena, e foi comprada ao Snr. Pedro Nolasco Baptista. Quem a pegar, leve a rua Imperial, no segundo sobrado n. 31, que se recompensará (DIÁRIO DE PERNAMBUCO, $1846 \mathrm{e}$, grifo nosso).

O mesmo jornal indica que, ao partir para o Rio de Janeiro, Nolasco levou em sua companhia uma mulher chamada Antonia Maria da Conceição (DIÁRIO DE PERNAMBUCO, 1846d), a qual infelizmente não foi possível precisar o nível de relação estabelecido com o músico. O que se sabe é que, mais de uma década e meia depois (junho de 1862), o artista foi acompanhado por outro cativo particular em uma viagem de retorno do Ceará para Pernambuco: "passageiros do vapor nacional Jaguaribe, [...]: Pedro Nolasco Baptista e um escravo" (DIÁRIO DE PERNAMBUCO, 1862a).

A inclusão de seu nome por anos seguidos no Almanak Laemmert e as notícias e anúncios publicados em jornais cariocas e pernambucanos nos dão conta de que Nolasco atuou seguidamente como professor particular de música, ensinando teoria musical, canto, violão e diversos instrumentos de sopro (oficleide, flauta, clarinete, dentre outros). Silva afirma que "em 1847, o Sr. Pedro Nolasco Baptista já era conhecido como professor e, como tal, apresentou seus alunos Manoel Galdino da Costa Rego e Henrique Mercês Janhsen, em 1862, ambos executantes de oficleide" (2006: 212). Outrossim, em muitas ocasiões, o músico foi apontado pela imprensa pernambucana e cearense como mestre de bandas, orquestras e/ou colégios, o que demonstra que sua atuação, no campo pedagógico, foi abrangente e intensa. 
Diversas de suas composições, com destaque para as obras orquestrais e as peças para oficleide, foram performadas nos principais teatros pernambucanos, muitas das quais tocadas e/ou regidas pelo próprio Nolasco. A Tab. 3 apresenta a lista que foi possível reunir através dos periódicos do período, embora o número deva ser significativamente maior, uma vez que, muitas vezes, termos como "abertura" , "variações", "fantasia", "capricho", "solo", e assim por diante, foram utilizados para descrever obras tocadas ou regidas pelo músico sem a indicação expressa de um compositor (ou seja, algumas de tais peças, pelo menos, poderiam ser composições do próprio Nolasco).

\begin{tabular}{|c|c|c|c|c|}
\hline Obra & Instrumentação & Ano & Local & Fonte \\
\hline "solo de oficleide" & $\begin{array}{c}\text { Oficleide basso (solista) e } \\
\text { banda de música }\end{array}$ & 1841 & Theatro Recife (PE) & $\begin{array}{c}\text { Diário de Pernambuco } \\
\text { (1841) }\end{array}$ \\
\hline $\begin{array}{c}\text { "variações ou fantasias } \\
\text { de oficleide" }\end{array}$ & Oficleide & 1845 & $\begin{array}{c}\text { Theatro Público } \\
\text { Recife (PE) }\end{array}$ & $\begin{array}{c}\text { Diário de Pernambuco } \\
\text { (1845) }\end{array}$ \\
\hline $\begin{array}{c}\text { "brilhante ouvertura" } \\
\text { A Batalha de Badajoz }{ }^{18}\end{array}$ & Poema Sinfônico & 1853 & $\begin{array}{c}\text { Theatro de Santa } \\
\text { Isabel, Recife (PE) }\end{array}$ & $\begin{array}{c}\text { Diário de Pernambuco } \\
\text { (1853) }\end{array}$ \\
\hline A Guerra da Criméa 19 & $\begin{array}{c}\text { Comédia teatral em 2 atos } \\
\text { "ornada de música" }\end{array}$ & 1855 & $\begin{array}{c}\text { Theatro de Santa } \\
\text { Isabel, Recife (PE) }\end{array}$ & $\begin{array}{c}\text { Diário de Pernambuco } \\
\text { (1855) }\end{array}$ \\
\hline "uma de suas melhores \\
ouverturas" & Abertura orquestral & 1856 & $\begin{array}{c}\text { Theatro de Santa } \\
\text { Isabel, Recife (PE) }\end{array}$ & $\begin{array}{c}\text { Diário de Pernambuco } \\
\text { (1856c) }\end{array}$ \\
\hline 3 fantasias para oficleide & Oficleide & 1862 & $\begin{array}{c}\text { Theatro de Santa } \\
\text { Isabel, Recife (PE) }\end{array}$ & $\begin{array}{c}\text { Diário de Pernambuco } \\
\text { (1862c) }\end{array}$ \\
\hline Cavatina & Oficleide & 1863 & $\begin{array}{c}\text { Theatro de Santa } \\
\text { Isabel, Recife (PE) }\end{array}$ & $\begin{array}{c}\text { Diário de Pernambuco } \\
\text { (1863a) }\end{array}$ \\
\hline A Bela Pernambucana & Abertura orquestral & 1865 & $\begin{array}{c}\text { Theatro de Santa } \\
\text { Isabel, Recife (PE) }\end{array}$ & $\begin{array}{c}\text { Diário de Pernambuco } \\
\text { (1865) }\end{array}$ \\
\hline Isabel, Recife (PE)
\end{tabular}

Tab. 3. Lista de composições de Pedro Nolasco Baptista coletadas a partir de menções nominais no jornal Diário de Pernambuco.

Fonte: elaboração do autor.

Infelizmente, todas estas obras encontram-se perdidas ou extraviadas, o que não nos permite estabelecer, ainda, uma crítica sobre o trabalho composicional de Nolasco ou mesmo avaliar alguns dos aspectos estilísticos de sua produção. Trata-se de um músico que atuou boa parte de sua vida ainda na primeira metade do século XIX e os registros impressos ou manuscritos no Brasil desse período são raros, ainda mais em Pernambuco.

A par disso, vale destacar que o seu trabalho como maestro (seja de orquestras ou de bandas) foi provavelmente o traço mais vitorioso de sua carreira musical, levando-o

18 Embora não haja expressamente uma indicação de que a obra foi composta por Nolasco nas duas fontes que coletamos que a mencionam, apenas a indicação de que a mesma pertencia "ao seu repertório", Silva acredita que esta peça era de autoria do músico pernambucano: "como compositor, Pedro Nolasco Baptista assinou como de sua autoria A Batalha de Badajoz, que deveria ser um poema sinfônico" (2006: 213, grifo original).

19 Título completo: Guerra da Criméa ou a Conquista de uma praça russa. 
a dirigir dezenas de espetáculos musicais e/ou teatrais nos palcos de sua terra natal. Silva comenta que Nolasco "foi, por algum tempo, regente de orquestra do teatro de Santa Isabel, exercendo grande influência junto aos colegas, podendo, por algumas vezes, arregimenta-los e movimentar inesquecíveis noitadas musicais no referido teatro" (2006: 212). O músico também se destacou na direção de bandas militares e/ou de polícia, conquistando, nestes postos, remunerações significativas e o respeito e a admiração de seus comandados.

O pioneirismo de sua atividade como instrumentista também não pode ser desconsiderado. Na sociedade pernambucana, o músico foi o responsável por divulgar amplamente os instrumentos de sopro fora dos círculos militares, inserindo-os em diversos benefícios e/ou apresentações que integravam o calendário cultural da província. Neste sentido, sua flauta e oficleide chegaram a acompanhar a voz célebre da cantora italiana Augusta Candiani. Durante os anos que viveu no Rio de Janeiro, chegou a ser considerado "o 1을 oficleide que tem aparecido no império" nas notas de divulgação de suas apresentações (JORNAL DO COMMERCIO, 1847b). Ademais, Nolasco foi possivelmente o primeiro músico pernambucano de maior prestígio a protagonizar solos de violão nos teatros recifenses, instrumento que também empunhou em palcos cariocas.

Apesar do trabalho musical contínuo por mais de três décadas e do notório reconhecimento alcançado entre os seus pares, parece certo que Nolasco alternou tempos mais confortáveis com os de sinuosas dificuldades financeiras, motivadas pela eventual perda deste ou daquele emprego ou ainda por um número de alunos de música abaixo do esperado. Certamente os anos finais de sua vida foram os mais difíceis, quando a soma da idade avançada, a saúde fragilizada e o impedimento físico para ensinar ou reger (suas atividades musicais mais recorrentes) chegaram a motivar apresentações coletivas para ajudá-lo.

A partir do material levantado, esta pesquisa se propôs a realizar um apontamento inicial sobre a trajetória do músico, intentando estabelecer uma memória sobre um personagem que pairava esquecido nos estudos sobre o tema. Em futuras pesquisas, este primeiro esforço deve ser desdobrado com a ampliação do espectro alcançado (sobretudo no que diz respeito aos contextos em que ele se articulou) e uma crítica mais aprofundada às fontes, o que nos permitirá aquilatar de modo mais seguro a posição de Nolasco no ambiente musical brasileiro de meados do século XIX.

Não obstante ser um dos raros personagens com formação ampla e atuação diversa que foram registrados pela imprensa pernambucana a partir da década de 1830 , talvez a maior contribuição de Nolasco resida justamente no fato dele ter se dedicado exclusivamente à música, no Brasil, em um período no qual, com poucas exceções, a regra era que as atividades musicais fossem combinadas com algum outro ofício para contornar as dificuldades financeiras de se sobreviver unicamente através da arte. Apesar de acabar sua vida tendo que contar com a generosidade dos amigos, Pedro Nolasco Baptista assumiu-se inteira e devotamente como músico. Assim viveu...

\section{E assim morreu.}




\section{Referências}

ALMANAK LAEMMERT (Almanak Administrativo, Mercantil e Industrial do Rio de Janeiro). Professores de Música. Rio de Janeiro: Eduardo e Henrique Laemmert: Ed. 05, 1848, p. 296 [313 no campo de busca].,

Professores de Música. Rio de Janeiro: Eduardo e Henrique Laemmert: Ed. 05, 1848 , p. 340 [362 no campo de busca].,

Professores de Música. Rio de Janeiro: Eduardo e Henrique Laemmert: Ed. 06, 1849 , p. 274 [291 no campo de busca].

Professores de Música. Rio de Janeiro: Eduardo e Henrique Laemmert: Ed. 07, 1850, p. 305 [328 no campo de busca].

Professores de Música. Rio de Janeiro: Eduardo e Henrique Laemmert: Ed. 08, 1851, p. 309 [340 no campo de busca].

. Professores de Música. Rio de Janeiro: Eduardo e Henrique Laemmert: Ed. 09, 1852 , p. 372 [399 no campo de busca].

. Professores de Música. Rio de Janeiro: Eduardo e Henrique Laemmert: Ed. 10, 1853, p. 382 [409 no campo de busca].

AUGUSTO, Antonio J. Henrique Alves de Mesquita: da pérola mais luminosa à poeira do esquecimento. Rio de Janeiro: Folha Seca, 2014.

DINIZ, Jaime C. Músicos Pernambucanos do Passado. Recife: Ed. Universitária UFPE, 1979.

SILVA, José Amaro Santos da. Música e Ópera no Santa Isabel: subsídio para a história e o ensino da música no Recife. Recife: Ed. Universitária UFPE, 2006.

TABORDA, Marcia E. Violão e Identidade Nacional: Rio de Janeiro 1830/1930. Tese de Doutorado. Programa de Pós-Graduação em História Social. Rio de Janeiro: UFRJ/IFCS, 2004.

\section{Periódicos}

CORREIO MERCANTIL, e instructivo, político, universal, Publicações a pedido, Rio de Janeiro (RJ), Ed. 153, 2 jun. 1853, p. 1.

DIÁRIO DE PERNAMBUCO, Avizos Particulares, Pernambuco (PE), Ed. 11, 14 jan. 1831, p. 3. , Theatro de Tarde, Pernambuco (PE), Ed. 392b, 29 mai. 1832, p. 3. Promotoria da Comarca do Recife, Pernambuco (PE), Ed. 277, 22 dez. 1836a, p. 2. Publicação a pedido, Pernambuco (PE), Ed. 85, 19 abr. 1836b, p. 3. Pernambuco (PE), Ed. 117, 01 jun. 1837, p. 2. Prefeitura, Pernambuco (PE), Ed. 78, 09 abr. 1839, p. 2. 
Theatro, Pernambuco (PE), Ed. 226, 16 out. 1841, p. 3.

Avisos diversos, Pernambuco (PE), Ed. 238, 25 out. 1844, p. 3.

Pernambuco (PE), Ed. 245, 03 nov. 1845, p. 3.

Commando das Armas, Pernambuco (PE), Ed. 89, 22 abri. 1846a, p. 2.

Avisos Diversos, Ed. 93, 27 abri. 1846b, p. 3.

Avisos Diversos, Ed. 125, 03 jun. 1846c, p. 4.

Movimento do Porto, Ed. 139, 26 jun. 1846d, p. 2.

Avisos Diversos, Pernambuco (PE), Ed. 177, 12 ago. 1846e, p. 3.

Parte oficial/Governo da Província, Pernambuco (PE), Ed. 122, 31 mai. 1850, p. 1.

Theatro de Apollo, Pernambuco (PE), Ed. 28, 04 fev. 1851, p. 2.

Communicado, Pernambuco (PE), Ed. 23, 29 jan. 1852a, p. 1.

Theatro de Apollo, Pernambuco (PE), Ed. 74, 01 abri. 1852b, p. 2.

Theatro de Apollo, Pernambuco (PE), Ed. 83, 14 abri. 1852c, p. 3.

Theatro de Santa Isabel, Pernambuco (PE), Ed. 183, 17 ago. 1852d, p. 2.

Theatro de Santa Isabel, Pernambuco (PE), Ed. 120, 01 jun. 1853, p. 2.

Theatro de Santa Isabel, Pernambuco (PE), Ed. 248, 26 out. 1855, p. 3.

Theatro de Santa Isabel, Pernambuco (PE), Ed. 197, 21 ago. 1856a, p. 3.

Theatro de Santa Isabel, Pernambuco (PE), Ed. 258, 3 nov. 1856b, p. 5.

Theatro de Santa Isabel, Pernambuco (PE), Ed. 278, 25 nov. 1856c, p. 3.

Theatro de Santa Isabel, Pernambuco (PE), Ed. 282, 29 nov. 1856d, p. 3.

Theatro de Santa Isabel, Pernambuco (PE), Ed. 291, 11 dez. 1856e, p. 3.

Theatro de Santa Isabel, Pernambuco (PE), Ed. 12, 16 jan. 1857a, p. 3.

Theatro de Santa Isabel, Pernambuco (PE), Ed. 187, 18 ago. 1857b, p. 3.

Passageiros do vapor nacional, Pernambuco (PE), Ed. 143, 23 jun. 1862a, p. 2.

Theatro de Santa Isabel, Pernambuco (PE), Ed. 242, 20 out. 1862b, p. 3.

Theatro de Santa Isabel, Pernambuco (PE), Ed. 287, 13 dez. 1862c, p. 3.

Gratidão, Pernambuco (PE), Ed. 294, 22 dez. 1862d, p. 3.

Theatro de Santa Isabel, Pernambuco (PE), Ed. 246, 27 out. 1863a, p. 3.

Theatro de Santa Isabel, Pernambuco (PE), Ed. 176, 04 ago. 1863b, p. 3.

Theatro de Santa Isabel, Pernambuco (PE), Ed. 167, 24 jul. 1865, p. 3.

JORNAL DO COMMERCIO, Movimento do Porto, Rio de Janeiro (RJ), Ed. 267, 26 nov. $1846 a$, p. 3.

Rio de Janeiro (RJ), Ed. 305, 03 nov. 1846b, p. 3.

Rio de Janeiro (RJ), Ed. 320, 18 nov. 1846c, p. 4.

Rio de Janeiro (RJ), Ed. 325, 23 nov. 1846d, p. 3.

Theatros, Rio de Janeiro (RJ), Ed. 190, 11 jul. 1847a, p. 4.

Correspondencia, Rio de Janeiro (RJ), Ed. 191, 12 jul. 1847b, p. 3.

Theatros, Rio de Janeiro (RJ), Ed. 91, 31 mar. 1848, p. 4.

O CEARENSE (CE), Parte Official, Ceará, Ed. 1503, 20 dez. 1861, p. 1.

O LiBeral PeRnAmBUCO (PE), Avisos Diversos, Pernambuco (PE), Ed. 414, 27 fev. 1854, 


\section{p. 3.}

Theatro de S. Izabel, Pernambuco (PE), Ed. 1240, 25 nov. 1856a, p. 3. Theatro de S. Izabel, Pernambuco (PE), Ed. 1245, 01 dez. 1856b, p. 2. , Theatro de S. Isabel, Pernambuco (PE), Ed. 1254, 12 dez. 1856c, p. 3. , Theatro de S. Isabel, Pernambuco (PE), Ed. 1457, 19 ago. 1857, p. 3.

O PUBLICADOR, Annuncios, Paraíba (PB), Ed. 966, 23 nov. 1865a, p. 4. Declaração, Paraíba (PB), Ed. 967, 24 nov. 1865b, p. 4.

PEDRO II, Ceará [capital e Maranguape] (PE), Ed. 98, 30 abr. 1861, p. 3. , Ceará [capital e Maranguape] (PE), Ed. 147, 1 jul. 1862, p. 2. 